\title{
Partisipasi Pembelajaran Siswa Dalam Pembelajaran Dengan Classroom Rules
}

\author{
Ayu Kristiana Noviyanti' ${ }^{1}$ Eunice Widyanti Setyaningtyas ${ }^{2}$ \\ 1 Jurusan Pendidikan Guru Sekolah Dasar, Universitas Kristen Satya Wacana, Salatiga, Indonesia \\ ${ }^{2}$ Jurusan Pendidikan Guru Sekolah Dasar, Universitas Kristen Satya Wacana, Salatiga, Indonesia
}

\section{Abstract}

This study aims to: (1) Determine the effect of applying classroom rules in participation in teaching students in grades 5 (2) Determine the level of success of the effect of applying classroom rules in participation in teaching students in grades 5 Classroom rules are a set of rules which help organize learning activities, not just a routine or habit but in practice is also based on a standard that will have a positive impact on student behavior both in learning and everyday attitudes. This type of research is experimental research with research design Quasi Experimental Design. Instruments data collection using questionnaires, observations and interviews. Hypothesis testing using t-test and two independent samples t-test two different paired sample with SPSS 16.0. The results showed that: (1) the results of pre-test and post-test participation learning experimental class increased after applying classroom rules is higher than pre-test participation study before applying classroom rules with an average participation of learning by 52904 and the average after applying classroom learning participation rules amounted to 55 761; (2) Participation of higher learning experimental class of classes controls $(t=2.342>$ tabel $5 \%=2,021)$. Thus the application of classroom rules affect the increased participation of student learning. Application of the rules Clasroom done optimally will affect the formation of character and the effect on student achievement.
\end{abstract}

\section{Keywords:}

Classroom rules,

Learning participation, Eben haezer 03 christian elementary school

\section{Pendahuluan}

Pendidikan dalam Undang-undang No. 20, Tahun 2003 Pasal 3 menyebutkan, pendidikan nasional bertujuan untuk mengembangkan potensi peserta didik agar menjadi manusia yang beriman dan bertaqwa kepada Tuhan YME, berakhlak mulia, sehat, cakap, kreatif, madiri dan menjadi warga demokratis serta tanggung jawab. Tercapainya tujuan pendidikan nasional dapat memberikan manfaat bagi manusia itu sendiri dan orang lain, karena semua akan kembali pada nilai luhur pribadinya sebagai manusia.

Herimanto \& Winarno (2010) menyatakan memanusiakan manusia berarti perilaku untuk senantiasa menghargai dan menghormati harkat dan derajat manusia yang lainnya. Oleh karena itu manusia patut mendapatkan pendidikan yang berkualitas. Proses pendidikan yang terjadi tidak terlepas dari proses interaksi manusia dengan lingkungan sekitar. Terdapat tiga macam lingkungan yang akan menjadi tempat berlangsungnya pendidikan yaitu keluarga, sekolah, dan masyarakat.

Sekolah adalah pusat pendidikan guru berperan sebagai media penyampaian ilmu. Peran guru dalam mewujudkan kualitas SDM yang berkualitas merupakan tugas dan tanggung jawab yang harus dilaksanakan sebaik mungkin. Tugas dan tanggung jawab guru di sekolah dimulai dari bagaimana guru mendidik siswanya sebagai manusia yang berbudi luhur melalui pendidikan karakter berupa penanaman nilai-nilai kehidupan. Guru yang dalam pelaksanaannya dapat menjalankan tugas dan tanggung jawabnya dengan maksimal, maka ia dapat mengelola kelas hingga sedemikian rupa dan menciptakan suasana belajar yang kondusif dan interaktif yang akan membuat pembelajaran akan berlangsung secara optimal.

Adam \& Decey dalam (Uzer, 2006:7) mengemukakan bahwa peranan dan kompetensi guru dalam belajar-mengajar meliputi banyak hal yaitu guru sebagai pengajar, pemimpin kelas, pembimbing, pengatur lingkungan, partisipan, ekspeditor, perencana, supervisor, motivator, dan konselor. Beberapa pernyataan di atas dapat disimpulkan bahwa seorang guru tidak hanya menyampaikan ilmu tapi juga

* Corresponding author.

E-mail Addresses: ayukristiana1@gmail.com (Ayu Kristiana Noviyanti), eunice.widyanti@gmail.com (Eunice Widyanti Setyaningtyas) 
berperan untuk membimbing siswanya. Selain itu, keterampilan yang dimiliki guru hendaknya dapat memberikan pengalaman bagi peserta didik, sehingga pengalaman yang mereka dapatkan dapat mereka terapkan dalam proses interaksi dengan lingkungan sekitar. Pengalaman yang mereka dapatkan, dapat berupa hal yang positif atau negatif.

Lingkungan masyarakat dan sekolah adalah lingkungan anak yang akan membuat anak melakukan proses interaksi dan bertemu dengan berbagai macam karakter orang baik itu dengan teman sebayanya atau dengan orang lain yang usianya lebih tua. Maka dari itu pengalaman belajar yang mereka telah dapatkan dari pendidikan di sekolah atau secara formal dapat dijadikan sebagai pengetahuan kontrol anak terhadap pengaruh buruk yang ada di lingkungannya. Selain itu, kebiasaan anak di dalam kelas merupakan kebiasaan yang diperolehnya saat berinteraksi sosial terhadap lingkungannya. Yang menjadi masalah adalah apabila anak mempunyai kebiasaan bersikap negatif setelah melakukan proses interaksi dan menimbulkan masalah di dalam kelas, pengaruh negatif ini akan mempengaruhi perilaku teman-temannya yang lain. Dampak dari pengaruh negatif ini akan membentuk kelompok bermain dengan konotasi negatif.

Lingkungan yang kurang mendukung akan menjadi penghambat terbentuknya sikap disiplin siswa (misbehavior). Perilaku anak yang negatif tidak hanya akan memberikan gangguan pada temanteman di kelasnya tapi juga akan menggangu proses belajar mengajar yang sedang terjadi di dalam kelas, selain itu perilaku negatif anak akan membuat perhatian siswa lain akan berkurang dalam mengikuti sebuah pembelajaran. Mengganggu teman lainnya akan memberikan dapak tidak hanya bagi fisik tapi juga psikis anak.

Suasana di lingkungan belajar harus dirancang dengan kondisi khusus yang dapat menggiring siswa pada perubahan pengetahuan dan perilaku. Semakin kodusif suasana pembelajaran kelas, maka semakin tinggi pula partisipasi dan prestasi belajar yang dicapai. Pengelolaan kelas yang dilakukan oleh guru selama kegiatan pembelajaran berguna untuk mempertahankan situasi kelas agar selalu kondusif. Kondisi kelas yang kondusif dapat tercipta apabila terjadi interaksi dua arah dari siswa dengan guru. Siswa turut berpartisipasi aktif dalam proses pembelajaran sesuai dengan arahan guru, serta dapat saling menghormati dan menghargai dengan sesama siswa. Peran guru dalam mengelola kelas adalah sebagai pemimpin, untuk dapat menjadi pemimpin yang baik guru harus peka dan cerdas dalam menyikapi permasalahan yang terjadi dalam kegiatan belajar mengajar dalam kelas. Permasalahan misbehavior yang dilakukan siswa dalam proses belajar mengajar harus dicegah dan diatasi agar siswa tidak menganggap jal itu sebagai suatu pembiaran. Strategi pengelolaan kelas diperlukan untuk mencegah dan mengatasi jika tantangan (misbehavior) ini terjadi dalam proses belajar mengajar.

Mc Donnald \& Hershman (2011:39) mengatakan bahwa untuk mengatasi permasalahan dalam kaitannya dengan perilaku siswa, guru harus memiliki prosedur-prosedur dan peraturan-peraturan yang tetap. Prosedur dan peraturan inilah yang akan menjadi kerangka dasar untuk membangun kebiasaankebiasaan baik di lingkungan belajar. Prosedur dan peraturan ini berisi ekspektasi dan penguatan guru kepada siswa mengenai apa yang dapat mereka lakukan dan apa yang sebaiknya tidak mereka lakukan selama proses belajar mengajar berlangsung. Prosedur dan peraturan tidak semata-mata dibuat untuk mengekang dan membatasi sikap dan perilaku siswa. Lebih dari itu, penerapan prosedur dan peraturan harus dapat membangkitkan kesadaran di dalam diri siswa bahwa keteraturan dan kedispilinan akan membawa dampak yang positif bagi proses belajar mengajar yang mereka ikuti. Melalui classroom rules guru memberikan kesempatan bagi siswa untuk berkontribusi menciptakan suasana kelas yang kondusif.

Classroom rules secara umum memang diartikan sebagai seperangkat aturan dan prosedur suatu kelas yang menjabarkan tanggung jawab siswa sebagai anggota kelas. Namun classroom rules bukanlah sekedar rangkaian peraturan yang digunakan untuk menegakkan disiplin kelas. Terselip nilai-nilai yang mampu membangkitkan kesadaran dan membentuk kepribadian peserta didik tentang cara bersikap dan berperilaku. Nilai-nilai inilah yang akan membentuk nurani para peserta didik untuk melihat indahnya proses belajar mengajar jika tercipta kenyamanan, keteraturan, kedispilinan, dan harmoni di dalam lingkungan belajar mereka.

Siswa tidak hanya sebagai pelaku namun siwa juga ikut berperan dalam pembuatan classroom rules. Melalui cara ini para siswa dapat melihat manfaat dan makna dari adanya sejumlah prosedur dan peraturan di dalam kelas mereka. Siswa juga akan menjadi lebih bertanggung jawab atas prosedur dan peraturan yang mereka buat. Secara otomatis para siswa akan lebih berkomitmen untuk mematuhi prosedur dan peraturan yang telah disepakati bersama.

Strategi pengelolaan kelas seperti classroom rules akan jauh lebih bermanfaat daripada memberikan hukuman atau konsekuensi ketika misbehavior sudah terjadi. Guru yang mengelola kelas dengan baik dapat menjalankan tugas mendidik dengan efektif. Waktu pembelajaran di kelas yang 
terbatas tidak hanya habis untuk mengkondisikan siswa terutama yang memiliki permasalahan dengan perilaku, sehingga tujuan pembelajaran dapat tercapai secara optimal.

Peneliti melakukan pengamatan dalam kelas 5A dan 5C di SD Kristen 03 Salatiga, peneliti menemukan sejumlah masalah dalam pengelolaan kelas dalam kaitannya dengan perilaku siswa yang mengganggu. Perilaku mengganggu siswa antara lain: 1) bermain di dalam kelas sewaktu diberi kesempatan untuk berdiskusi dalam kelompok; 2) siswa sibuk mengobrol sewaktu guru sedang memberikan materi; 3) siswa masuk kelas tidak tepat waktu setelah jam istirahat; 4) siswa berceletuk saat guru menjelaskan materi dengan tujuan menggundang tawa siswa lainnya; 5) ketidaksiplinan dalam hal waktu. Masalah dalam pengelolaan kelas yang sering terjadi di kelas $5 \mathrm{~A}$ adalah hampir semua dari jumlah siswa tidak memiliki partisipasi pembelajaran yang terlihat dari perilaku siswa yang menggangu teman lainnya atau bisa disebut tidak sesuai dengan aturan yang ditujukan untuk mengajak siswa berparstisipasi dalam pembelajaran.

Berdasarkan pengamatan tampak dengan jelas guru mengalami kesulitan untuk mengontrol situasi kelas. Guru sudah berupaya untuk membuat proses belajar mengajar menjadi menyenangkan dengan menggunakan reward jika siswa mampu menjawab pertanyaan yang diajukan. Media dan strategi pembelajaran yang digunakan oleh guru cukup interaktif. Meski sudah membuat beberapa terobosan, guru tetap kesulitan mendapatkan partisipasi siswa selama proses pembelajaran. Peneliti melihat adanya disfungsi peran guru sebagai pengelola kelas yang efektif. Melihat perilaku siswa di dalam kelas tersebut maka perlu dilakukan tindakan, seperti pendapat Eka (2011) jika mengamati dari pola perilaku siswa di dalam kelas maka kedisiplinan perlu ditingkatkan. Untuk menunjang terwujudnya sikap disiplin tersebut dibutuhkan stimulus dari lingkungan agar siswa mendapatkan dukungan atas tidakannya tersebut.

Penelitian ini dilakukan untuk mengetahui partisipasi anak dalam mengikuti pembelajaran dan memberikan pengetahuan kepada guru kelas agar mampu mengelola kelas berupa penerapan peraturan kelas sehingga tercipta sikap disiplin siswa yang berdampak pada suasana pembelajaran kondusif antara guru dan peserta didik.

\section{Metode}

Metode penelitian yang digunakan adalah kuasi eksperimen. Sugiono(2010:89) mengemukakan penelitian eksperimen dapat dikatakan sebagai metode penelitian yang dipergunakan untuk mencari akibat perlakuan tertentu terhadap yang lain dalam kondisi yang terkendalikan. Pengujian untuk membuktikan adanya hubungan sebab-akibat antara dua variabel menggunakan instrumen yang sudah dirumuskan bertujuan untuk memperoleh data akurat selanjutnya diproses sehingga menjawab hipotesis awal.

Penelitian ini dilakukan pada kelas V SD Kristen 03 Salatiga semester II tahun pelajaran 2016-2017 yang berlokasi di Jln. Jendral Sudirman 111B Salatiga. Penelitian ini akan dilaksanakan pada bulan Januari sampai Maret, pada kelas V(A) dan V(C) semester II tahun pelajaran 2016-2017. Alasan peneliti memilih kelas tersebut karena menemukan permasalahan dalam pembelajaran berupa partisipasi pembelajaran yang masih rendah.

Dalam penelitian ini terdapat dua variabel yaitu variabel independen (bebas) dan variabel dependen (terikat). a.)Variabel Independen yang sering disebut dengan variabel bebas. Variabel independen merupakan variabel yang mempengaruhi atau menjadi sebab perubahan atau timbulnya variabel dependen (terikat) (Sugiyono, 2011: 4). Variabel independen atau variabel bebas dalam penelitian ini adalah penerapan classroom rules. b.) Variabel dependen sering disebut sebagai variabel terikat. Variabel dependen merupakan variabel yang dipengaruhi atau yang menjadi akibat karena adanya variabel independen (Sugiyono: 2011: 4). Dalam penelitian ini yang menjadi variabel dependen adalah partisipasi siswa dalam mengikuti pembelajaran.

Adapun prosedur yang dilakukan oleh peneliti dalam melaksanakan penelitian berupa:

1. Menentukan subjek penelitian

2. Merumuskan istrumen partisipasi

pembelajaran dalam bentuk pengamatan, dan angket sesuai tujuan penelitian

3. Melakukan pengamatan partisipasi

4. Memberikan perlakuan

5. Mengambil data dan mengolah data

Teknik yang digunakan dalam penelitian ini adalah 1.) Wawancara, yang digunakan dalam penelitian ini adalah semi wawancara terstruktur. Pertanyaan yang diajukan berdasarkan pedoman yang telah disiapkan, tetapi jawabannya bebas. Wawancara akan dilakukan setelah penerapan classroom rules pada pembelajaran. Hasil wawancara akan menjadi pembanding hasil penelitian. Wawancara akan dilakukan oleh peneliti dan guru kelas. 2.) Angket partisipasi pembelajaran yang akan diisi oleh siswa. 3.) 
Observasi atau pengamatan yang akan dilakukan dalam penelitian ini, yakni melakukan pengamatan tentang partsipasi anak dalam mengikuti pembelajaran yang menerapkan dan tidak menerapkan classroom rules.

\section{Hasil dan Pembahasan}

Penelitian ini membahas mengenai pengaruh classroom rules terhadap partisipasi pembelajaran siswa. Penelitian ini membandingkan dua data hasil penelitian antara kelas yang menerapkan classroom rules dalam proses pembelajaran dengan kelas yang tidak menerapkan classroom rules dalam proses pembelajaran.

Hasil penelitian observasi yang didapatkan berupa latar belakang atau faktor yang menyebabkan siswa memiliki partisipasi rendah dalam pembelajaran adalah lingkungan belajar yang kurang mendukung dan pengelolaan kelas yang kurang maksimal menyebabkan siswa kurang fokus dalam memperhatikan penjelasan dari guru, lebih suka bermain daripada belajar, lambat dalam mengerjakan tugas-tugas belajar, menjadi siswa yang pendiam dan tidak suka mengajukan pertanyaan maupun pendapat, suka mengganggu temannya, tidak mau maju kedepan ketika diberikan perintah guru untuk menjawab pertanyaan. Setelah peneliti melakukan observasi pada kelas eksperimen sebelum pemberian perlakuan penerapan classroom rules, peneliti melakukan wawancara terhadap guru kelas dan guru mata pelajaran mengenai apa yang dibutuhkan siswa supaya siswa memiliki partisipasi yang tinggi terhadap pembelajaran. Hasil wawancara dan observasi inilah yang dijadikan patokan oleh peneliti untuk memberikan perlakuan yang tepat kepada siswa sebagai subjek penelitian. Peneliti akan memberikan pretest angket untuk siswa sebelum melakukan penerapan classroom rules untuk mengetahui partisipasi siswa dalam mengikuti pembelajaran.

Berdasarkan data dari hasil observasi, wawancara dan angket pretest, peneliti menetapkan treatment (perlakuan) berupa pemberian bantuan kepada anak yang bersangkutan sesuai dengan program yang telah disusun untuk menangani masalah yang ada dalam bentuk penerapan classroom rules untuk meningkatkan partisipasi siswa dalam pembelajaran. Treatment yang dapat diberikan oleh peneliti adalah membimbing guru untuk dapat memberi motivasi pada siswa agar berpartisipasi dalam pembelajaran (berani bertanya, memberikan pendapat, dapat berdiskusi antara guru dengan siswa, memberikan perhatian dan respon kepada semua aktivitas yang dilakukan siswa) serta mengontrol tingkah laku siswa selama pembelajaran (menerapkan peraturan kelas yang disepakati oleh guru dan siswa, memberikan teguran).

Hasil observasi selama pelaksanaan pembelajaran dengan penerapan classroom rules yang dilakukan pada kelas eksperimen, diketahui adanya perubahan terhadap perkembangan pada perilaku siswa yaitu siswa sekarang sudah ikut berpartisipasi aktif dalam pembelajaran seperti memberanikan diri untuk bertanya, berdiskusi, mengikuti dan melakukan tugas yang diberikan oleh guru dengan baik, memberi perhatian dan fokus selama pembelajaran, menghargai serta memberikan respon yang baik pada teman dan guru yang sedang berbicara didepan kelas, melaksanakan peraturan yang telah disepakati dan mendengarkan teguran yang diberikan oleh guru, menjaga kondisi kelas tetap kondusif selama pembelajaran dan saling mengingatkan dan menegur jika temannya melakukan pelanggaran atau bertingkah laku yang tidak sesuai selama pembelajaran berlangsung Hal tersebut diperkuat dengan hasil angket posttest siswa setelah menerapkan classroom rules mengalami peningkatan skor yang membuktikan bahwa siswa telah mengalami perubahan dalam partisipasi pembelajaran dan hasil wawancara dengan guru yang menyatakan bahwa penerapan menggunakan classroom rules membuat pembelajaran lebih kondusif dan tidak hanya pada saat pembelajaran namun sikap siswa menjadi lebih baik karena penerapan classroom rules dirasa mendidik dan membentuk karakter siswa semakin baik dalam bertindak.

Perbandingan skor rata-rata partisipasi siswa sebelum dan sesudah penerapan classroom rules pada kelas eksperimen dan kelas kontrol dapat dilihat pada Gambar 1 sebagai berikut: 


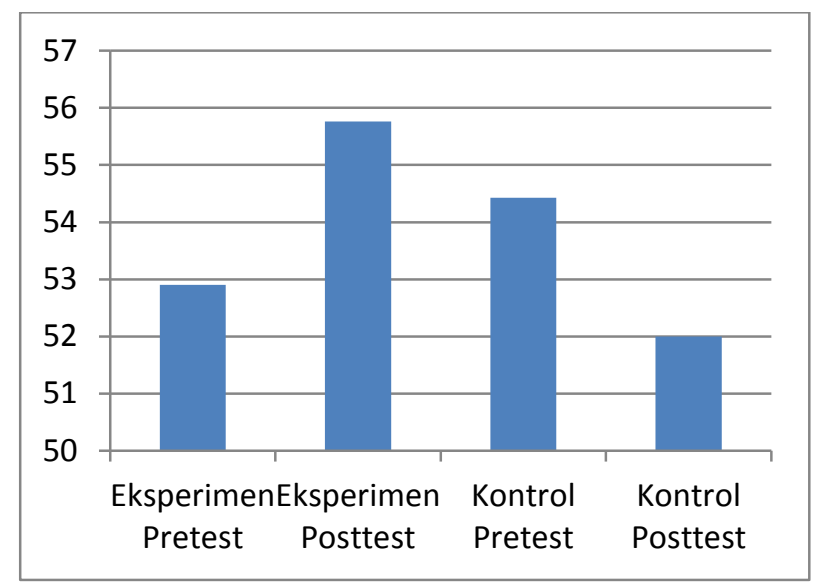

Gambar 1.Diagram Perbandingan Hasil Angket Partisipasi Pretest-Posttest Kelas Eksperimen dan Kelas Kontrol

Pada diagram 1 diperlihatkan sebelum penerapan perlakuan pada proses pembelajaran diketahui bahwa kelas ekperimen memiliki skor rata-rata partisipasi pembelajaran sebesar 52,904 dan kelas kontrol sebesar 54,428. Berdasarkan hasil penelitian diketahui bahwa penerapan classroom rules memberi kontribusi terhadap tingginya partisipasi pembelajaran siswa. Hal ini ditunjukkan pada deskripsi data dimana kelas eksperimen memiliki skor rata-rata partisipasi pembelajaran sebesar 55,761 dan kelas kontrol memiliki skor rata-rata partisipasi pembelajaran sebesar 52.000. Dapat dilihat bahwa skor rata-rata pertisipasi pembelajaran kelas eksperimen lebih tinggi setelah menggunakan penerapan classroom rules dari kelas kontrol sebesar 3.76.

Pengujian pada penelitian ini menggunakan uji t pre-test dan post-test kelas eksperimen dengan Paired Sampe T Test (Uji Beda Dua Sampel Berpasangan) dan uji t post-test kelas eksperimen dan post-test kelas kontrol dengan Independent Sample Test.

Paired Sampe T Test merupakan uji beda dua sampel berpasangan.

Sampel berpasangan merupakan subjek yang sama namun mengalami perlakuan yang berbeda. Pengujian pada Paired Sampe T Test ini dilakukan untuk mengetahui ada tidaknya peningkatan skor berupa pengaruh kelas eksperimen sebelum dan setelah menerima penerapan classroom rules.

Tabel 1 Hasil Uji t Berpasangan Pre-test dan Post-test Kelas Eksperimen

Paired Samples Statistics

\begin{tabular}{|ll|l|l|l|l|}
\hline & & Mean & N & Std. Deviation & Std. Error Mean \\
\hline Pair 1 & PreAngketEksperimen & 52.9048 & 21 & 6.60988 & 1.44239 \\
& PostAngketEksperimen & 55.7619 & 21 & 6.24424 & 1.36260 \\
\hline
\end{tabular}

Paired Samples Correlations

\begin{tabular}{|ll|l|l|l|}
\hline & \multicolumn{1}{|c|}{$\mathrm{N}$} & \multicolumn{1}{c|}{ Correlation } & Sig. \\
\hline Pair 1 & $\&$ & 21 & .938 & .000 \\
& $\begin{array}{l}\text { PreAngketEksperimen } \\
\text { PostAngketEksperimen }\end{array}$ & & & \\
\hline
\end{tabular}

Paired Samples Test

\begin{tabular}{|c|c|c|c|c|c|c|c|c|c|}
\hline & & \multicolumn{5}{|c|}{ Paired Differences } & \multirow{3}{*}{$\mathrm{T}$} & \multirow{3}{*}{ Df } & \multirow{3}{*}{$\begin{array}{l}\text { Sig. (2- } \\
\text { tailed) }\end{array}$} \\
\hline & & \multirow[b]{2}{*}{ Mean } & \multirow{2}{*}{$\begin{array}{l}\text { Std. } \\
\text { Deviation }\end{array}$} & \multirow{2}{*}{$\begin{array}{l}\text { Std. Error } \\
\text { Mean }\end{array}$} & \multicolumn{2}{|c|}{\begin{tabular}{|llr}
$95 \%$ & Confidence \\
Interval & of $\quad$ the \\
Difference & \\
\end{tabular}} & & & \\
\hline & & & & & Lower & Upper & & & \\
\hline Pair & $\begin{array}{l}1 \\
\text { PreAngketEksperimen } \\
- \\
\text { PostAngketEksperimen }\end{array}$ & 2.85714 & 2.28661 & .49898 & -3.89799 & -1.81629 & 5.726 & 20 & .000 \\
\hline
\end{tabular}


Pada tabel Paired Sample Statistics menunjukan bahwa rata-rata partisipasi sebelum dan sesudah penerapan classroom rules. Sebelum penerapan classroom rules rata-rata partisipasi siswa dari jumlah 21 siswa adalah sebanyak 52.9, setelah mendapat perlakuan berupa penerapan peraturan kelas jumlah ratarata adalah sebesar 55.7 .

Hasil uji Paired Sample Correlations menunjukan bahwa korelasi antar dua variabel adalah sebesar 0.938 dengan sig sebesar 0.000. hal ini menunjukan bahwa korelasi antar dua rata-rata partisipasi sebelum dan sesudah penerapan adalah kuat dan signifikan.

Nilai t hitung pada tabel Paired Sample T test adalah sebesar 5.726 dengan signifikasi .000, karena signifikansi $<0.05$ maka dapat disimpulkan bahwa rata-rata partisipasi sesudah dan sebelum perlakuan adalah berbeda dan dapat dinyatakan bahwa perlakuan penerapan classroom rules berpengaruh pada partisipasi siswa dalam mengikuti pembelajaran.

Independent Sample T-test bertujuan untuk mengetahui ada tidaknya perbedaan yang signifikan nilai post-test pada kelas eksperimen dan kelas kontrol. Kesimpulan penelitian dinyatakan signifikan apabila thitung $>$ ttabel pada taraf signifikansi $5 \%$ dan nilai $\mathrm{p}<0.05$. berikut adalah tabel uraian dari posttest kelas eksperimen dan kelas kontrol.

Tabel 2 Hasil Uji t Post-test Kelas Eksperimen dan Kelas Kontrol

Independent Samples Test

\begin{tabular}{|c|c|c|c|c|c|c|c|c|c|}
\hline & \multicolumn{2}{|c|}{$\begin{array}{c}\text { Levene's Test for } \\
\text { Equality of } \\
\text { Variances } \\
\end{array}$} & \multicolumn{7}{|c|}{ t-test for Equality of Means } \\
\hline & \multirow[t]{2}{*}{$\mathrm{F}$} & \multirow[t]{2}{*}{ Sig. } & \multirow[t]{2}{*}{$\mathrm{T}$} & \multirow[t]{2}{*}{ df } & \multirow[t]{2}{*}{$\begin{array}{l}\text { Sig. }(2- \\
\text { tailed) }\end{array}$} & \multirow[t]{2}{*}{$\begin{array}{c}\text { Mean } \\
\text { Difference }\end{array}$} & \multirow[t]{2}{*}{$\begin{array}{l}\text { Std. Error } \\
\text { Difference }\end{array}$} & \multicolumn{2}{|c|}{$\begin{array}{l}\text { 95\% Confidence } \\
\text { Interval of the } \\
\text { Difference }\end{array}$} \\
\hline & & & & & & & & Lower & Upper \\
\hline $\begin{array}{l}\text { Partisipasi Equal variances } \\
\text { assumed }\end{array}$ & 5.483 & .024 & 2.342 & 40 & .024 & -3.76190 & 1.60639 & -7.00855 & -.51526 \\
\hline $\begin{array}{l}\text { Equal variances } \\
\text { not assumed }\end{array}$ & & & 2.342 & 33.536 & .025 & -3.76190 & 1.60639 & -7.02815 & -.49566 \\
\hline
\end{tabular}

Hasil pengujian data menunjukan bahwa data berdistribusi normal dan penggujian hipotesis dilakukan dengan menggunakan uji t beda dua sampel berpasangan dan uji t dua sampel independen. Uji $t$ digunakan untuk menguji hipotesis alternatif (Ha) sehingga dapat diketahui Ha diterima atau ditolak. Penelitian ini menguji hipotesis.

Ho : Partisipasi kelas kontrol < Partisipasi kelas eksperimen Partisipasi pembelajaran siswa yang menerapkan classroom rules sama dengan siswa yang tidak menerapkan classroom rules.

Ha : Partisipasi kelas kontrol > Partisipasi kelas eksperimen Partisipasi pembelajaran siswa yang menerapkan classroom rules tidak sama dengan siswa yang tidak menerapkan classroom rules.

Kriteria pengujian Jika signifikansi $<0,05$ maka ha diterima dan jika signifikansi $>0,05$ Ha ditolak atau dengan thitung $>$ ttabel maka $\mathrm{H}_{\mathrm{a}}$ diterima.

Berdasarkan data yang didapat selama penelitian, pengujian hipotesis dilakukan untuk melihat signifikansi perbedaan partisipasi pembelajaran antara kelas eksperimen sebelum dan sesu dah perlakuan serta perbedaan antara kelas eksperimen dengan kelas kontrol. Pengujian dilakukan dengan uji t dua sampel berpasangan variabel partisipasi pembelajaran kelas ekperimen dan uji t dua sampel independen variabel partisipasi pembelajaran antara kelas eksperimen dengan kelas kontrol. Diketahui bahwa thitung $>$ ttabel, yaitu: 2,342 > 2,021. Hasil thitung lebih besar ttabel, maka hipotesis alternatif diterima. Hasil analisis juga menunjukkan signifikansi 0,024<0,05 yang berarti Ha diterima. Hal ini menunjukkan bahwa partisipasi pembelajaran siswa yang menerapkan classroom rules tidak sama dengan siswa yang tidak menerapkan classroom rules. Hasil ini dipertegas dengan pernyataan guru pengampu mata pelajaran IPS, Bahasa Indonesia serta guru kelas VA dan VC dalam wawancara yang menyatakan bahwa penerapan classroom rules menjadikan siswa lebih disiplin dalam pembelajaran dan membuat suasana belajar menjadi kondusif.

Sebagaimana diketahui bahwa berkurangnya misbehavior siswa dapat meningkatkan kualitas pembelajaran. Kualitas pembelajaran yang baik salah satunya tercermin dari partisipasi pembelajaran yang tinggi. Pengelolaan kelas yang bersifat preventif ini dapat guru terapkan secara konsisten dalam proses pembelajaran di kelas. Penerapan classroom rules selama proses pembelajaran akan membangun kesadaran individu untuk menciptakan kondisi belajar yang baik. Hal ini sesuai dengan yang 
dikemukakan Parkay (2011) bahwa pengelolaan atau manajemen kelas dapat mencegah, atau meminimalkan, masalah perilaku. Berkurangnya misbehavior membawa pengaruh positif pada partisipasi pembelajaran.

\section{Simpulan dan saran}

Berdasarkan hasil yang diperoleh dari penelitian ini maka dapat diambil kesimpulan sebagai berikut: Terdapat perbedaan partisipasi pembelajaran siswa yang menerapkan classroom rules dengan siswa yang tidak menerapkan classroom rules. Hal ini ditunjukkan dari hasil uji-t dengan nilai thitung sebesar 2,342 lebih besar dari ttabel sebesar 2,021 yang dapat disimpulkan bahwa Hipotesis alternatif diterima yaitu "Partisipasi pembelajaran siswa yang menerapkan classroom rules tidak sama dengan siswa yang tidak menerapkan classroom rules". Siswa yang kelasnya menerapkan classroom rules memiliki partisipasi pembelajaran yang lebih tinggi dibanding dengan kelas yang tidak menerapkan serta memiliki adanya perubahan terhadap perkembangan pada perilaku siswa seperti siswa yang sudah ikut berpartisipasi aktif dalam pembelajaran seperti memberanikan diri untuk bertanya, berdiskusi dengan guru dan temannya, mengikuti dan melakukan tugas yang diberikan oleh guru dengan baik, memberi perhatian dan fokus selama pembelajaran, menghargai serta memberikan respon yang baik pada teman dan guru yang sedang berbicara didepan kelas, melaksanakan peraturan yang telah disepakati dan mendengarkan teguran yang diberikan oleh guru, menjaga kondisi kelas tetap kondusif selama pembelajaran dan saling mengingatkan dan menegur jika temannya melakukan pelanggaran atau bertingkah laku yang tidak sesuai selama pembelajaran berlangsung. Penerapan classroom rules ini berpengaruh positif pada perilaku siswa. Pengaruh penerapan classroom rules pada partisipasi siswa saat pembelajaran dapat dilihat melalui hasil skor partisipasi pembelajaran siswa kelas eksperimen setelah perlakuan mencapai 55,761 yang sebelumnya memiliki skor 52,904 dan angka normalitas $>0.005$ yang berarti data pada penelitian ini berdistribusi normal.

Berdasarkan hasil penelitian yang telah dilakukan oleh penulis, ada beberapa hal yang penulis sarankan yaitu peningkatan kualitas pembelajaran pada SD Kristen 03 dirasa perlu untuk lebih ditingkatkan lagi. Hal ini dapat dilakukan dengan penggunaan pengelolaan kelas yang dalam pelaksaannya melibatkan peran guru dan siswa secara bersama-sama. Penggunaan pengelolaan kelas yang benar akan memberikan dampak positif pada partisipasi siswa dalam mengikuti pebelajaran sehingga pada akhirnya siswa juga memperoleh prestasi yang baik karena mereka telah menaruh partisipasi selama pembelajaran. Penggelolaan yang dapat diterapkan pada pembelajaran adalah dengan menggunakan penerapan classroom rules atau peraturan kelas. Supaya penerapan peraturan kelas dapat dilakukan dengan maksimal ada baiknya apabila pihak sekolah menerapkan peraturan tersebut pada siswa sejak masuk sekolah atau dimulai sejak siswa berada di kelas 1 yang akan membuat siswa terbiasa pada keadaan tersebut, atau dapat diterapkan pada siswa diawal semester pada setiap pembelajaran. Penerapan peraturan juga akan lebih baik apabila peraturan yang diterapkan tersebut dalam pembuatannya atas kesepakatan bersama antara guru dengan siswa dan dalam pembuatannya hanya menekankan poin-poin yang diperlukan saja agar membuat siswa lebih mudah untuk mengingat peraturan yang telah dibuat, misalnya 1.) saling menghormati; 2.)bersikap tertib saat pembelajaran; 3.) tidak melakukan kekerasan. Penggunaan peraturan kelas dapat dipantau oleh guru kelas dengan cara guru menunjuk satu siswa sebagai pengawas dan menyediakan buku pelanggaran yang akan diisi oleh pengawas berupa pelanggaran yang dilakukan oleh anggota kelasnya selama pembelajaran, supaya berlaku dengan adil guru akan mengganti pengawas setiap hari sesuai dengan urut absen. Pemberian buku pelanggaran oleh pengawas kepada guru dapat dilakukan pada pagi hari setelah renungan atau sebelum pelajaran pertama dimulai. Siswa yang terbukti melakukan pelanggaran dapat diberi nasihat atau peringatan dari guru kelas, akan lebih baik apabila guru mendengarkan alasan siswa tersebut melakukan pelanggaran. Selain pemberian nasihat dan peringatan guru juga dapat memberikan reward kepada siswa yang tidak melakukan pelanggaran peraturan kelas, reward dapat diberikan dengan memberikan sticker yang dapat ditempel pada reward chart. Disisi lain guru juga dapat membuat buku pelanggaran dimana siswa menulis sendiri pelanggaran yang telah ia lakukan, peran guru pada penerapan ini adalah membantu siswa untuk berfikir dan mengevaluasi terhadap dirinya yang akan membuat siswa menjadi lebih tanggungjawab dan mengerti terhadap kesalahan yang telah ia lakukan, sehingga kesalahan yang dilakukan tadi tidak diulangi lagi. 


\section{Daftar Rujukan}

Akbar, S. (2010). Jurnal Ilmu Pendidikan. Model Pembelajaran Nilai Dan Karakter Berbasis Nilai-Nilai Kehidupan Di Sekolah dasar, 46-54.

Alber, R. (2015, September 3). Back to School: Rules and Routines in the Classroom. Retrieved November 2016, 28, from George Lucas Educational : https://www.edutopia.org/blog/rules-routines-schoolyear-start-classroom-management

Baharudin, \& Wahyuni. (2007). Belajar dan Pembelajaran. Yogyakarta: Andi.

Barden, P. A., \& Byrd, D. M. (1999). Methods for Effective Teaching. USA: Viacom Company.

Davies, L. (n.d.). Elementary Classroom Rules and Management. Retrieved January 2, 2017, from www.kellybear.com: http://www.kellybear.com/TeacherArticles/TeacherTip72.html

E, M. (2006). Implementasi Kurikulum 2004: Panduan Belajar KBK. Bandung: PT.Remaja Rosdakarya.

Eka, P. (2011). Manajemen Peserta Didik. Bandung: Alfabeta.

Evans, V. (2014). Classroom Management and Organization. Retrieved January 2017, 12, from http://www.ascd.org/publications/books/104135/chapters/Classroom-Management-andOrganization.aspx

Hamalik, O. (2002). Perencanaan Pegajaran Berdasarkan Pendekatan Sistem. Jakarta: Bumi Aksara.

Heri, G. (2012). Pendidikan KarakterKonsep dan Implementasi . Bandung : Alfabeta.

Indonesia, K. B. (2016). Retrieved December 13, 2016, from http://kbbi.web.id/kelola

Mach, D. (2010). Consequences For Breaking Class Rules.

Mandrel. (2015). How Good Classroom Rules Can Result in Good Classroom Behavior. Retrieved November 28, 2016, from https://www.goconqr.com/en/blog/good-classroom-rules-mean-good-classroombehavior/

McDonald, E. S., \& Hershman, D. M. (2011). Guru dan Kelas Cemerlang. Jakarta: PT.Indeks.

Parkay, F. W. (2011). Menjadi Seorang Guru. Jakarta : PT.Indeks.

Sadirman, A. (2004). Interaksi dan Motivasi Belajar Mengajar. Jakarta: PT.Raja Grafindo.

Santrock, J. W. (2009). Psikologi Pendidikan Edisi ke 3. Jakarta: Salemba Humanika.

Sastroputro, S. (1989). Partisipasi, Komunikasi, Persuasi, dan Disiplin. Bandung: PT.Remaja Rosdakarya.

Setyanta, S. (2013). Penerapan Peraturan Kelas. Implementation Written Rules Class Of Discipline On Grade 2 Elementary School Student, 1-10.

Slameto. (2003). Belajar dan Faktor - Faktor yang Mempengaruhinya. Jakarta: Rineka Cipta.

Stronge, J. H., Tucker, P. D., \& Hindmand, J. L. (2004). Handbook for Qualities of Effective Teachers.

Sugihartono. (2008). Psikologi Pendidikan. Yogyakarta: UNY Press.

Sugiyono. (2010). Statistika Untuk Penelitian. Bandung: Alfabeta.

Thomas, L. (1992). Educating For Character: How Our School Can Teach Respect and. New York: Batam Books.

Wina, S. (2005). Pembelajaran dan Implementasi Kurikulum Berbasis Kompetensi. Jakarta : Kencana Prenada Media Group.

Wuryandani, W. (2014). Jurnal Pendidikan Karakter. Internalisasi Nilai Karakter Disiplin Melalui Penciptaan Iklim Yang Kondusif Di SD Muhamadiyah Sapen Yogyakarta, 175-184. 